Louisiana State University

LSU Digital Commons

Faculty Publications

Department of Oceanography \& Coastal

Sciences

2-18-2008

Below- and Aboveground Biomass of Spartina alterniflora:

Response to Nutrient Addition in a Louisiana Salt Marsh

Faith A. Darby

R. Eugene Turner

euturne@lsu.edu

Follow this and additional works at: https://digitalcommons.Isu.edu/oceanography_coastal_pubs

Digitadrt of the Oceanography Commons

Commons

Network

Recommended Citation

barby, F. A., \& Turner, R. (2008). Below- and Aboveground Biomass of Spartina alterniflora: Response to

Nutrient Addition in a Louisiana Salt Marsh., 326-334. https://doi.org/10.1007/s12237-008-9037-8

This Article is brought to you for free and open access by the Department of Oceanography \& Coastal Sciences at LSU Digital Commons. It has been accepted for inclusion in Faculty Publications by an authorized administrator of LSU Digital Commons. For more information, please contact ir@lsu.edu. 


\title{
Below- and Aboveground Biomass of Spartina alterniflora: Response to Nutrient Addition in a Louisiana Salt Marsh
}

\author{
Faith A. Darby • R. Eugene Turner
}

Received: 9 January 2007 /Revised: 26 September 2007 / Accepted: 25 October 2007 / Published online: 16 February 2008

(C) Coastal and Estuarine Research Federation 2008

\begin{abstract}
The responses of Spartina alterniflora aboveand belowground biomass to various combinations of $\mathrm{N}, \mathrm{P}$, and $\mathrm{Fe}$ were documented in a 1-year field experiment in a Louisiana salt marsh. Five levels of $\mathrm{N}$ additions to $0.25 \mathrm{~m}^{2}$ plots resulted in $18 \%$ to $138 \%$ more live aboveground biomass compared to the control plots and higher stem densities, but had no effect on the amount of live belowground biomass (roots and rhizomes; R\&R). There was no change in the aboveground biomass when $\mathrm{P}$ or $\mathrm{Fe}$ was added as part of a factorial experiment of $+\mathrm{P},+\mathrm{N}$, and $+\mathrm{Fe}$ additions, but there was a $40 \%$ to $60 \%$ decrease in the live belowground biomass, which reduced the average R\&R:S ratio by $50 \%$. The addition of various combinations of nutrients had a significant affect on the belowground biomass indicating that the addition of $\mathrm{P}$, not $\mathrm{N}$, eased the need for root foraging activity. The end-of-the-growingseason N:P molar ratios in the live above- and belowground tissues of the control plot was 16.4 and 32.7, respectively. The relative size of the belowground standing stocks of $\mathrm{N}$ and $\mathrm{P}$ was higher than in the aboveground live tissues, but shifted downwards to about half that in fertilized plots. We conclude that the aboveground biomass was directly related to $\mathrm{N}$ availability, but not $\mathrm{P}$, and that the accumulation of belowground biomass was not limited by $\mathrm{N}$. We suggest that the reduction in belowground biomass with increased $\mathrm{P}$ availability, and the lower absolute and relative below-
\end{abstract}

\footnotetext{
F. A. Darby $\cdot$ R. E. Turner

Department of Oceanography and Coastal Sciences, Louisiana State University,

Baton Rouge, LA 70803, USA

R. E. Turner $(\bowtie)$

Coastal Ecology Institute, Louisiana State University,

Baton Rouge, LA 70803, USA

e-mail: euturne@1su.edu
}

ground standing stocks of $\mathrm{P}$ as plant tissue $\mathrm{N}: \mathrm{P}$ ratios increased, is related to competition with soil microbes for $\mathrm{P}$. One implication for wetland management and restoration is that eutrophication may be detrimental to long-term salt marsh maintenance and development, especially in organicrich wetland soils.

Keywords Belowground production · Salt marsh . Louisiana $\cdot$ Nutrients $\cdot$ Eutrophication $\cdot$ P limitation

\section{Introduction}

More than a dozen experiments have established that nitrogen limits the aboveground production of the salt marsh macrophyte Spartina alterniflora (Valiela and Teal 1974; Morris 1988; Blum 1993; Visser and Sasser 2006). The majority of the annual total biomass production occurs belowground, however, and reaches a higher peak in warmer climates (Valiela et al. 1976; Schubauer and Hopkinson 1984; Dame and Kenny 1986; Darby and Turner 2008a, b). The root and rhizome (R\&R) biomass resists erosion, contributes to the accumulation of organic matter as sea level rises and the marsh soils compact, and is the organic benthic matrix important to various feeding guilds, including those supporting commercially valuable fisheries. S. alterniflora R\&R production, however, may not be limited by nitrogen availability because these structures are foraging for nutrients in a P-limited soil microbial community (Sundareshwar et al. 2003; Huang and Morris 2005). In other words, the belowground production may be limited by phosphorous and nitrogen. This is a testable hypothesis we address in the experiments described herein.

The few studies on belowground production of $S$. alterniflora have neglected, with one exception, to study 
the effects of nutrient limitation on belowground plant production. Valiela et al. (1976) demonstrated that belowground biomass accumulation of S. alterniflora could be affected by different nutrient additions (various combinations of sewage sludge and urea fertilizer additions. Those fertilization experiments, however, did not isolate the effects of $\mathrm{P}$ additions because $\mathrm{P}$ was added only in combination with other nutrients. Besides $\mathrm{N}$ and $\mathrm{P}$, iron may also influence $S$. alterniflora production belowground through its role in flooded soil sulfur and phosphorus cycles. Giblin and Howarth (1984) showed how some pyrite in a Massachusetts salt marsh is seasonally oxidized to iron mineral in the growing season and reduced to pyrite in the fall and winter. If pyrite formation is reduced because soluble iron is removed by tidal flushing, then sulfides may accumulate and harm the plant. The amount and form of phosphorus is not directly controlled by the oxidationreduction potential in soils, but is indirectly influenced by its association with iron. Iron can be stored in the soil as iron precipitates and as ferric iron is reduced to create ferrous ions, but the soluble ferrous phosphates can be lost by flushing or transformed by microbes to other forms. Some iron may be precipitated in the oxidized rhizosphere (Ponnamperuma 1965). Iron supply to a plant, therefore, might result in more or less biomass accumulation, depending on how much $\mathrm{P}$ limits plant growth, and on the net effect of Fe transformation on P supply.

Improving our understanding of the relative importance of various nutrients on coastal marsh production is of heightened importance because of the dramatic rise and insidious impacts of nonpoint source pollution (Carpenter et al. 1998; Deegan 2002) and the ubiquitous influence of $\mathrm{N}$ over-enrichment (Vitousek et al. 1997; Rabalais 2002). It was the purpose of this study to document the response of the above- and belowground biomass of S. alterniflora to various combinations of $\mathrm{N}, \mathrm{P}$, and $\mathrm{Fe}$ in a factorial arrangement experiment conducted under field conditions.

\section{Methods and Materials}

The study was conducted in a S. alterniflora-dominated salt marsh located west of the Louisiana Universities Marine Consortium (LUMCON) laboratory, in Cocodrie, LA, USA $\left(29^{\circ} 15^{\prime} \mathrm{N}, 91^{\circ} 21^{\prime} \mathrm{W}\right)$. This is the same area studied by Darby and Turner (2008a) who describe the annual variation in the above- and belowground biomass of $S$. alterniflora in different plots. A monospecific stand of $S$. alterniflora was sampled from a series of boardwalks constructed to facilitate sampling and to minimize damage to the marsh. Two experiments were established consisting of $0.25 \mathrm{~m}^{2}$ plots with at least $0.5 \mathrm{~m}$ between plots and marked with white plastic piping to direct the proper placement of the fertilizer. Eighteen plots of triplicate treatments were manipulated by monthly additions of six levels of nitrogen $\left(0,46,93,186,372,744 \mathrm{~kg} \mathrm{ha}^{-1}\right.$ month $^{-1}$ ) designated as the C, N46, N93, N186, N372, and N744 plots, respectively. Eighteen plots of three treatments each were part of a $3 \times 6$ factorial arrangement in which various combinations of 744,22 , and $60 \mathrm{~kg} \mathrm{ha}^{-1}$ month- ${ }^{1}$ $\mathrm{N}$ (ammonium sulfate 33\%), $\mathrm{P}$ (superphosphate; $18 \%$ ), and Fe (ironite; $1 \%$ ), respectively, were broadcasted monthly at low tide beginning April 2004 through August 2004. These plots are labeled the C, N744, P, NP, NFe, PFe, and NPFe treatments (Fig. 1), and the shared plots for the $\mathrm{N}$ and factorial design were plots $\mathrm{C}$ and N744. The loading rates

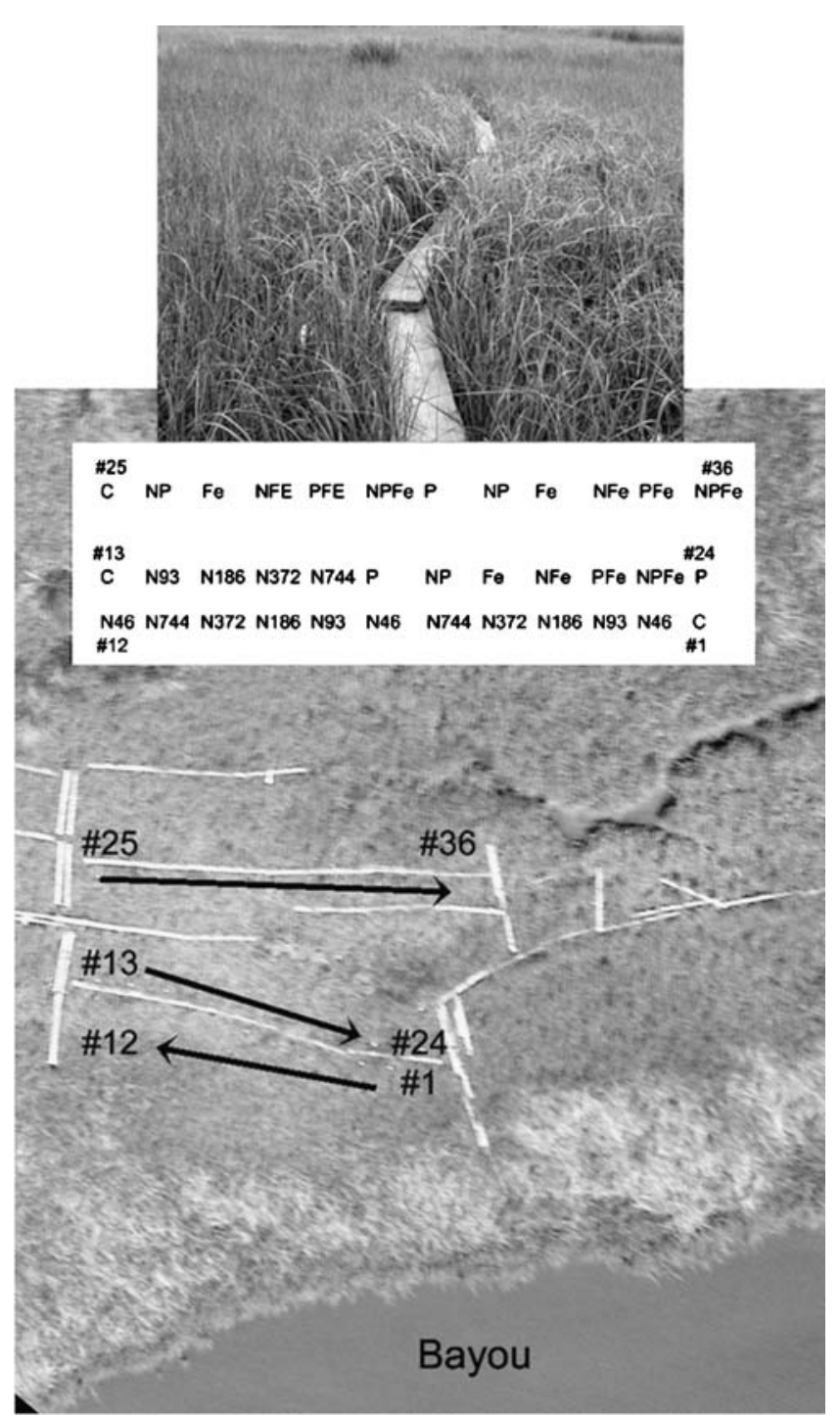

Fig. 1 An aerial and ground-level view of the arrangement of nutrient additions along boardwalks near the LUMCON facilities at Cocodrie, LA. The nutrient dose abbreviations are described in the text 


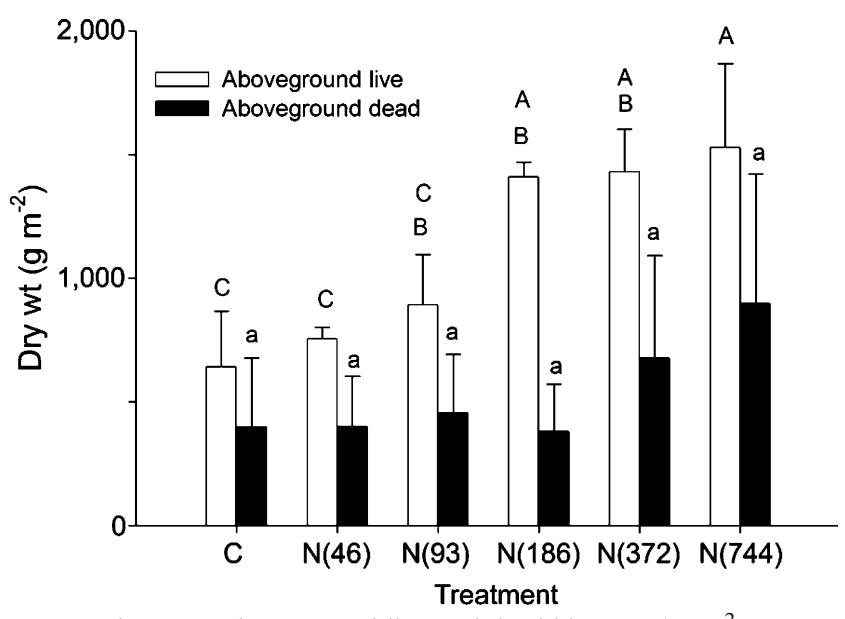

Fig. 2 The mean aboveground live and dead biomass $\left(\mathrm{g} \mathrm{m}^{-2}\right.$; mean \pm $1 \mathrm{SD})$ of three replicates of $\mathrm{N}$ treatment plots at the end of the growing season in 2004. Letters indicate the result of a Tukey's Studentized range test for differences in aboveground live and dead biomass by $\mathrm{N}$ treatment. Means with the same letters are not statistically different from each other (level of significance $<0.05$ ). $p<0.01$ for a linear contrast of live aboveground biomass vs. dose; but was not significant for dead aboveground biomass vs. dose

are within the range of $\mathrm{N}$ and $\mathrm{P}$ loadings in New England (Wigand et al. 2003) and the Gulf of Mexico (Turner and Rabalais 1999). Wigand et al. for example, measured $\mathrm{N}$ loading rates in Narragansett Bay to be as high as 10,243 $\mathrm{kg} \mathrm{ha}^{-1} \mathrm{~N}$ year ${ }^{-1}$, and Valiela et al. applied $\mathrm{N}$ at a rate of $100 \mathrm{~g} \mathrm{~m}^{-2}$ month $^{-1}$ from April through November. The migration of fertilizer out of the plots was not visually evident because there was a sharp distinction between the outside and inside of the plots (Fig. 1). PVC pipes with holes at the bottom were inserted into the center of each plot to collect porewater at $10 \mathrm{~cm}$ depth. Porewater was collected before the plot fertilization to avoid accidental additions of fertilizer to the porewater. The porewater pipes were aspirated of all of the standing water from the tube which was allowed to refill before drawing samples.

The aboveground biomass was harvested in September, 2005, and a stainless steel tube used to sample belowground biomass from the clipped plot. The vegetation was transported to the laboratory and analyzed as described by Darby and Turner (2008a). The biomass was subsequently separated into dead and live plant leaves, shoots, roots, and rhizomes. Dried plant material was ground and analyzed by the LSU Soil Testing and Plant Analysis Lab to determine the $\mathrm{N}$ and $\mathrm{P}$ content.

The N:P molar ratios of plant tissues were calculated to investigate whether the site was $\mathrm{N}$ limited or P limited. An $\mathrm{N}$ :P molar ratio $<33$ indicates $\mathrm{N}$ limitation, whereas a ratio of $\mathrm{N}: \mathrm{P}>33$ suggests $\mathrm{P}$ limitation (Koerselman and Meulemen 1996; USEPA 2002).

The results of a statistical analysis of the above- and belowground biomass and the stem density were compared to determine if the means were significantly different $(p<$ 0.05 ) based on Tukey's adjustment (factorial design) or a linear contrast (nitrogen addition experiment). The analysis was carried out using the general linear model procedure and $3 \times 6$ factorial arrangements (ANOVA; SAS 2002-2003).

\section{Results}

Aboveground Biomass

A statistically significant difference was seen in the amount of live aboveground biomass among the series of $\mathrm{N}$ treatments compared to that in the $\mathrm{C}$ plots $(p<0.01$; Fig. 2). The aboveground biomass in plots with added $\mathrm{N}$ was $18 \%$ to $138 \%$ higher than in the $\mathrm{C}$ plots, and ranged from $641 \pm$ $224 \mathrm{~g} \mathrm{~m}^{-2}$ (mean $\pm 1 \mathrm{SD}$ ) in the $\mathrm{C}$ plot to $1,527 \pm 340 \mathrm{~g} \mathrm{~m}^{-2}$ in plot N744. No statistically significant difference was seen among the N196, N372, and N744 plots, or among the C, N46, and N93 plots (Fig. 2). The aboveground dead biomass ranged from $397 \pm 279 \mathrm{~g} \mathrm{~m}^{-2}$ for the $\mathrm{C}$ plot to $897 \mathrm{~g} \mathrm{~m}^{-2} \pm$ 524 in plot N744 (Fig. 2). Results from the linear contrast indicate that there was a significant increase in live biomass with increasing amounts of $\mathrm{N}$ added $(p<0.01)$.

No statistically significant difference was observed in the amount of live aboveground biomass in the N, NP, or NFe plots (Fig. 3). There was, however, a statistically significant difference $(p<0.01)$ between the aboveground live biomass in the $\mathrm{C}, \mathrm{P}, \mathrm{Fe}$, and $\mathrm{PFe}$ plots when compared to the aboveground live biomass in the N, NP, and NFe plots (Fig. 3). The amount of dead aboveground biomass in the factorial arrangement

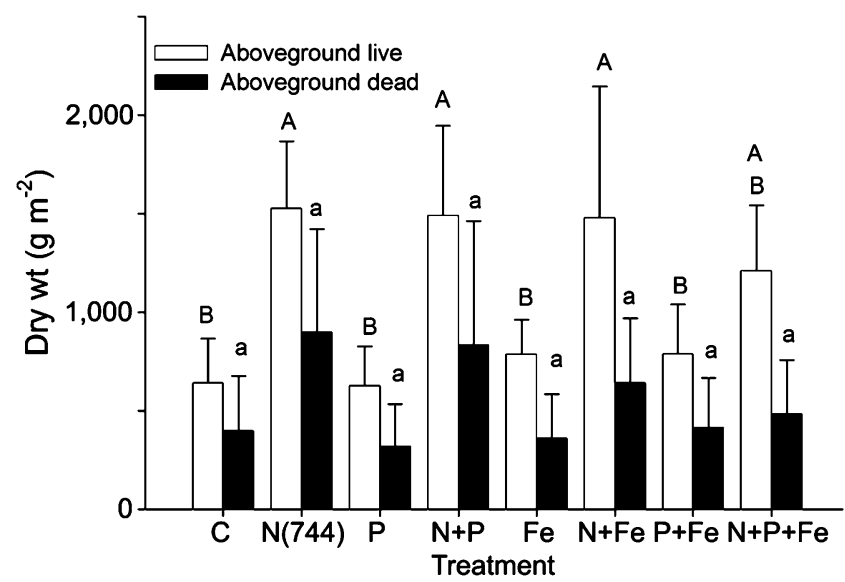

Fig. 3 The mean aboveground live and dead biomass $\left(\mathrm{g} \mathrm{m}^{-2}\right.$; mean \pm $1 \mathrm{SD})$ of three replicates of nutrient treatment plots. Letters indicate the results of a Tukey's Studentized range test for differences in aboveground live and dead biomass by nutrient treatment. Means with the same letters are not statistically different from each other (level of significance $<0.05$ ). Treatment dosages are $N=744, P=22$, and $\mathrm{Fe}=60$ $\mathrm{kg} \mathrm{ha}^{-1}$ month $^{-1}$ 
experiment ranged from 318 to $897 \mathrm{~g} \mathrm{~m}^{-2}$ and was not different among treatment plots (linear contrast $p>0.5$ ).

Similar patterns were seen in stem density and length with $\mathrm{N}$ fertilization. Stem density increased by $10-57 \%$ with increasing $\mathrm{N}$ addition and ranged from 308 (average) stems $\mathrm{m}^{-2}$ in the C plots to 463 stems $\mathrm{m}^{-2}$ in the N744 plots (Fig. 4). In addition, the average stem length increased by 11 to $23 \%$ above that in the $\mathrm{C}$ plots. No apparent changes in stem density or length were seen in the $\mathrm{P}, \mathrm{Fe}$ or PFe plots (Fig. 5). However, compared to the C plot, there was a $63 \%$ increase in stem density and a $28 \%$ increase in stem length in the NP plot. Stem density also increased in the NP and NFe plots, but the average stem length remained unchanged in all plots. (Fig. 5). In sum, nitrogen was implicated as a nutrient controlling the amount of biomass accumulating aboveground in all cases where changes occurred.

\section{Belowground Biomass}

The live R\&R biomass was distributed throughout the $0-30$ $\mathrm{cm}$ profile, with the majority of the biomass located in the 0 $10 \mathrm{~cm}$ depth layer for all treatment levels. The highest rhizome biomass among treatments were in the $\mathrm{C}$ plot and N46 plot (565.7 and $602.7 \mathrm{~g} \mathrm{~m}^{-2}$, respectively; Table 1). The largest amount of live rhizome in the 10-20 segments was $503.6 \mathrm{~g} \mathrm{~m}^{-2}$ for the N186 plot. The 20-30 segment with the lowest rhizome biomass was in the NP treatment $\left(7.7 \mathrm{~g} \mathrm{~m}^{-2}\right)$ and highest in the N46 plot (135.3 $\left.\mathrm{g} \mathrm{m}^{-2}\right)$.

No statistically significant differences in the live or dead belowground biomass were seen with the addition of $\mathrm{N}$ alone (Fig. 6). A statistically significant difference in the

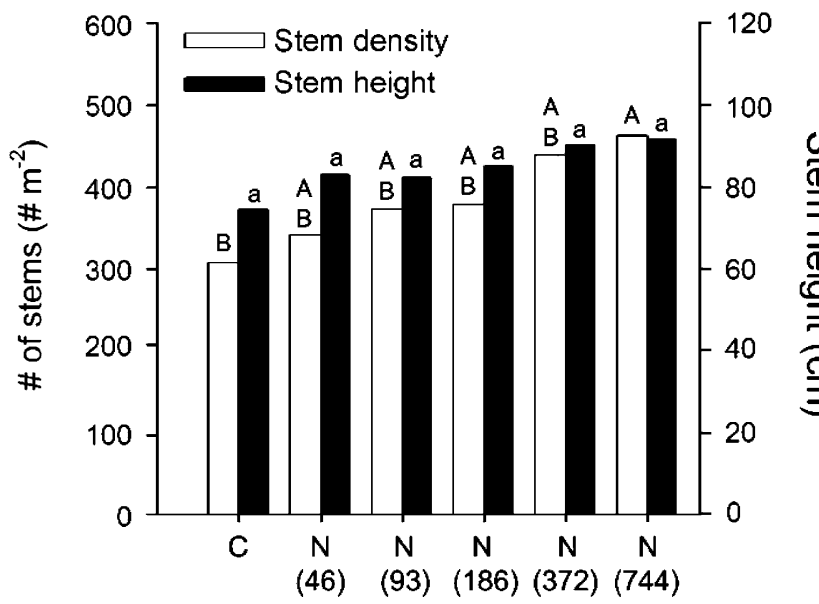

Fig. 4 The values of average stem density $\left(\mathrm{g} \mathrm{m}^{-2}\right)$ and length $(\mathrm{cm})$ for all treatments. A standard deviation is not shown and was $<10 \%$ of the mean in all samples. Letters indicate the results of a Tukey's Studentized range test for differences by nutrient treatment. Means with the same letters are not statistically different from each other (level of significance $<0.05$ ). $p<0.01$ for a linear contrast of both stem density and stem height vs. dose

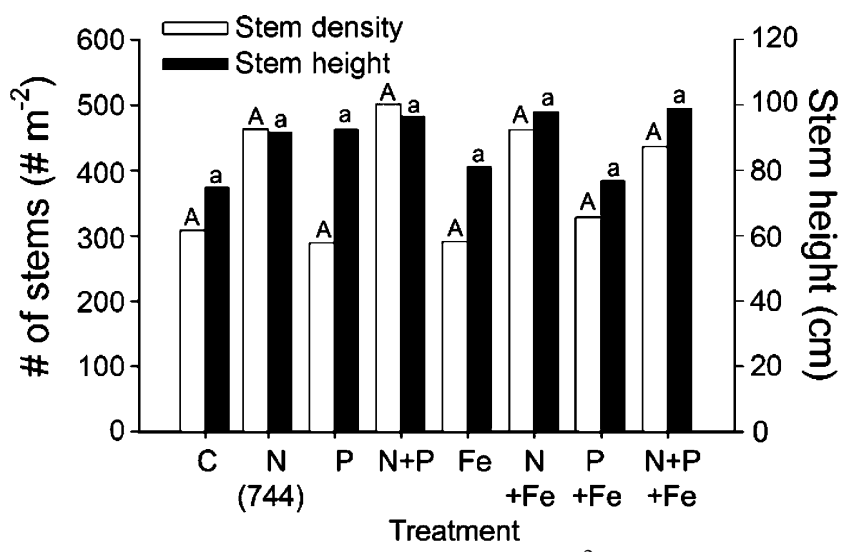

Fig. 5 The values of average stem density $\left(\mathrm{g} \mathrm{m}^{-2}\right)$ and length $(\mathrm{cm})$ for all treatments. A SD is not shown, and was $<10 \%$ of the mean in all samples. Means with the same letters are not statistically different from each other (level of significance $<0.05$ )

live belowground biomass $(p<0.01)$ was noted in the factorial arrangement experiment (Fig. 7). The live belowground biomass decreased by $40-60 \%$ with $\mathrm{P}$ and $\mathrm{Fe}$ additions, and also when $\mathrm{P}$ and $\mathrm{Fe}$ were added in combination with $\mathrm{N}$ (Fig. 7). The lowest live belowground biomass was in the NFe plot $\left(503 \mathrm{~g} \mathrm{~m}^{-2}\right)$. No difference, however, was seen in the amount of dead belowground biomass accumulation among the treatments. The average root + rhizome/shoot ratio for all treatment plots $(<1: 1)$ was below that of the $\mathrm{C}$ and the N46 treatments (2:1; Fig. 8). The belowground biomass did not decrease with added $\mathrm{N}$, but did change when $\mathrm{P}$ or $\mathrm{Fe}$ were added together, or in combination.

Standing Stocks of N (NSS), P (PSS), and Tissue Ratios

The nitrogen standing stock (NSS) in the aboveground live biomass was highest in the treatment plot with the highest $\mathrm{N}$ addition (N744; $18.7 \mathrm{~g} \mathrm{~N} \mathrm{~m}^{-2}$ ) and lowest in the $\mathrm{C}$ plots (6.4 $\mathrm{g} \mathrm{N} \mathrm{m}^{-2}$; Table 2). The phosphorous standing stock (PSS) in the aboveground live biomass was lowest in the $\mathrm{C}$ plots and increased as more $\mathrm{N}$ was added to the plots (Table 2). The PSS did not change with increasing biomass as much as the $\mathrm{N}$ did, and so the $\mathrm{N}: \mathrm{P}$ molar ratio in the aboveground live biomass was highest in the N744 plots (26.5) and lowest in the C plots (16.4). The NSS and PSS in the belowground live biomass were highest in the $\mathrm{N} 372$ plots $\left(26.5 \mathrm{~g} \mathrm{~N} \mathrm{~m}^{-2}\right.$ and $7.8 \mathrm{~g} \mathrm{P} \mathrm{m}^{-2}$, respectively). The $\mathrm{N}: \mathrm{P}$ molar ratio in the live belowground biomass was highest in the N744 plots (36.9) and lowest in C plots (32.7; Table 2).

In the factorial experiment, the PSS in the aboveground live biomass was highest in the NP plots $\left(1.97 \mathrm{~g} \mathrm{~m}^{-2}\right)$. The highest NSS for belowground live biomass was $12.5 \mathrm{~g} \mathrm{~m}^{-2}$ in the N744 plots (Table 3) The belowground live biomass with the highest PSS was $0.84 \mathrm{~g} \mathrm{~m}^{-2}$ in the N744 plots. The 
Table 1 The depth distribution of for live R\&R and the cumulative total $\left(\mathrm{g} \mathrm{m}^{-2}\right)$

\begin{tabular}{|c|c|c|c|c|c|c|c|c|}
\hline \multirow[t]{2}{*}{ Treatment $\left(\mathrm{g} \mathrm{ha}^{-1}\right.$ month $\left.^{-1}\right)$} & \multicolumn{3}{|c|}{ Live roots $\left(\mathrm{g} \mathrm{m}^{-2}\right)$} & \multicolumn{3}{|c|}{ Live rhizomes $\left(\mathrm{g} \mathrm{m}^{-2}\right)$} & \multicolumn{2}{|c|}{$\begin{array}{l}\text { Roots Rhizomes } \\
\text { Cumulative total }\end{array}$} \\
\hline & $0-10 \mathrm{~cm}$ & $10-20 \mathrm{~cm}$ & $20-30 \mathrm{~cm}$ & $0-10 \mathrm{~cm}$ & $10-20 \mathrm{~cm}$ & $20-30 \mathrm{~cm}$ & $0-30 \mathrm{~cm}$ & $0-30 \mathrm{~cm}$ \\
\hline 0.0 & 361.4 & 14.3 & 0.0 & 565.7 & 225.1 & 41.2 & 375.7 & 832.0 \\
\hline N (46) & 367.7 & 5.2 & 0.0 & 602.7 & 279.7 & 135.3 & 372.9 & 1017.7 \\
\hline N (93) & 232.4 & 2.1 & 0.0 & 534.0 & 171.2 & 53.6 & 234.5 & 758.7 \\
\hline N (186) & 355.5 & 4.2 & 3.5 & 293.3 & 170.5 & 44.2 & 363.2 & 507.9 \\
\hline N (372) & 474.2 & 4.5 & 2.1 & 271.3 & 503.6 & 78.3 & 480.8 & 853.2 \\
\hline $\mathrm{N}(744)$ & 419.9 & 1.0 & 0.0 & 174.3 & 248.0 & 66.8 & 420.9 & 489.1 \\
\hline $\mathrm{P}$ & 347.5 & 1.7 & 0.0 & 139.5 & 117.6 & 89.4 & 349.3 & 346.5 \\
\hline NP & 282.5 & 6.6 & 0.0 & 157.9 & 168.0 & 7.7 & 289.1 & 333.6 \\
\hline $\mathrm{Fe}$ & 315.9 & 8.0 & 0.0 & 173.2 & 181.6 & 36.2 & 323.9 & 391.0 \\
\hline $\mathrm{NFe}$ & 244.9 & 0.0 & 0.0 & 161.8 & 72.5 & 23.7 & 244.9 & 258.0 \\
\hline $\mathrm{PFe}$ & 297.8 & 17.0 & 0.0 & 30.6 & 142.6 & 135.3 & 314.8 & 308.6 \\
\hline $\mathrm{NFeP}$ & 295.7 & 0.3 & 0.0 & 150.6 & 155.2 & 14.3 & 296.0 & 320.0 \\
\hline
\end{tabular}

$\mathrm{N}: \mathrm{P}$ molar ratio for the aboveground live biomass in the factorial experiment was highest at the N744 plots (26.5) and the highest $\mathrm{N}: \mathrm{P}$ molar ratio in the belowground live biomass was in the NFe plots (38.5; Fig. 9). In summary, the accumulation of $\mathrm{N}$ and $\mathrm{P}$ and the $\mathrm{N}: \mathrm{P}$ ratios in aboveand belowground biomass were not in phase with each other in the two experiments.

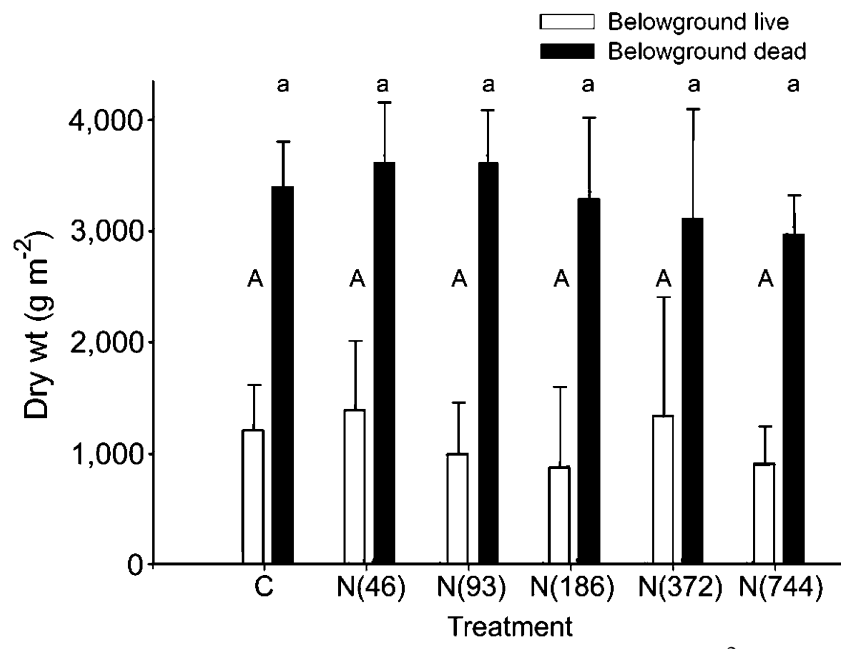

Fig. 6 The mean belowground live and dead biomass $\left(\mathrm{g} \mathrm{m}^{-2}\right.$; mean \pm $1 \mathrm{SD})$ of three replicates of $\mathrm{N}$ treatment plots. Letters indicate the results of a Tukey's Studentized range test for differences in the aboveground live and dead biomass by $\mathrm{N}$ treatment. Means with the same letters are not statistically different from each other (level of significance $<0.05$ ). $p$ was not significant for a linear contrast of live or dead belowground biomass vs. dose
Comparisons of Standing Stocks vs. Tissue Ratios and Dosages

The tissue molar ratios are directly related to the standing stocks of N, P, and live biomass aboveground, but not belowground (Fig. 10). Furthermore, the range of N:P ratios for the live aboveground biomass (16.4 to 26.8) is much greater than for the belowground biomass (31.2 to 38.5; Fig. 10b). The biomass of live aboveground material was directly related to the nitrogen dose (Fig. 10c). The

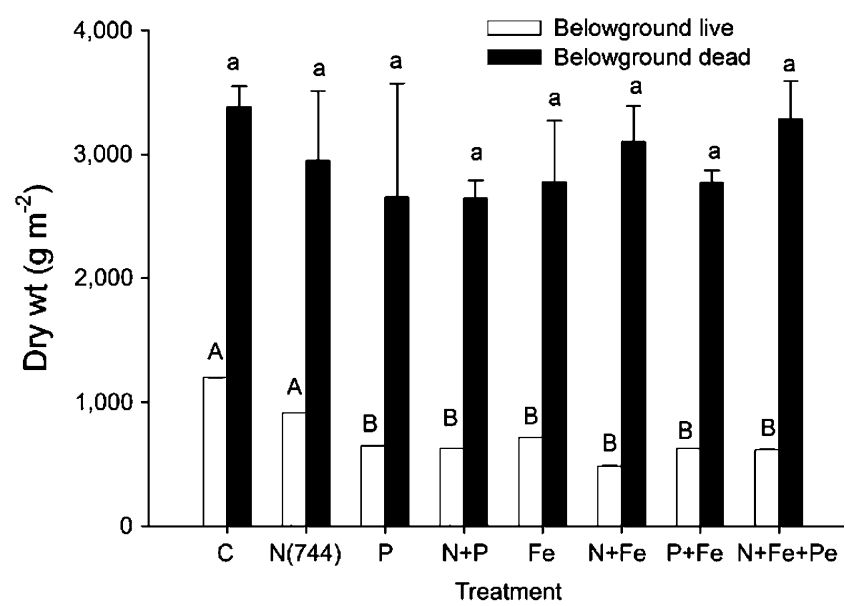

Fig. 7 The mean belowground live and dead biomass $\left(\mathrm{g} \mathrm{m}^{-2}\right.$; mean \pm $1 \mathrm{SD}$ ) of three replicates of nutrient treatment plots. Letters indicate the result of a Tukey's Studentized range test for differences in aboveground live and dead biomass by nutrient treatment. Means with the same letters are not statistically different from each other (level of significance $<0.05$ ). There was no statistical difference among treatments. The treatment dosages were $N=744, P=22$ and $\mathrm{Fe}=60 \mathrm{~kg} \mathrm{ha}^{-1}$ month $^{-1}$ 


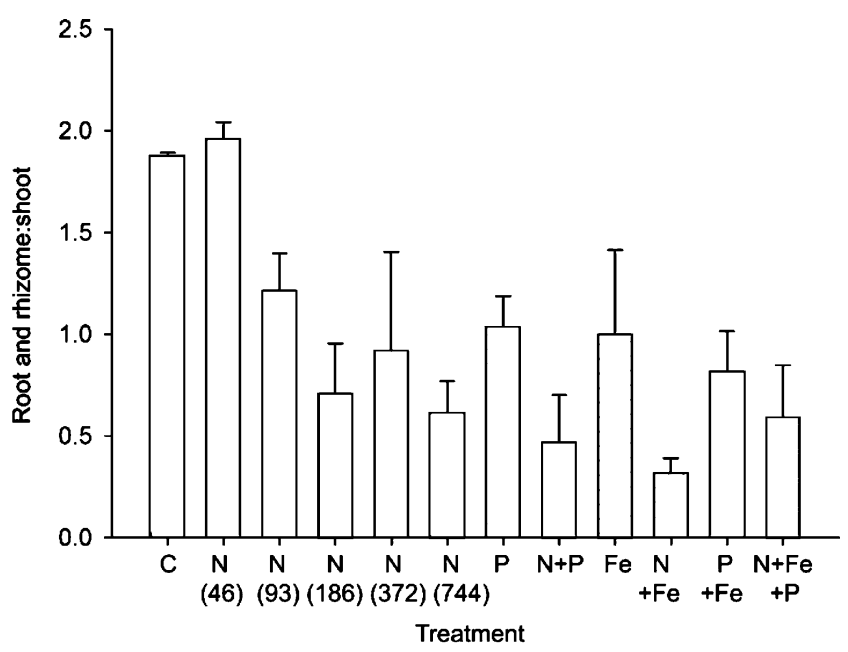

Fig. 8 The R\&R:shoot ratio (mean $\pm 1 \mathrm{SE}$ ) in the various treatments

relationship between the $\mathrm{N}$ dosage and belowground biomass appears to be negative, but $p=0.10$. The belowground live biomass in plots with either $\mathrm{P}$ or $\mathrm{Fe}$, however, were lower than in the $\mathrm{C}$ and N744 plots (Figs. 7 and 10d). The results shown in Fig. 10 indicate that the PSS plant biomass accumulating above- and belowground is responding to $\mathrm{N}, \mathrm{P}$, and $\mathrm{Fe}$ additions in very different ways, that the variations in biomass accumulations are not simply controlled by the nutrient loading of one element, and that the elemental ratios in tissues reflect, albeit in imperfectly understood ways, the net effect of several influential physiological factors.

The ammonium concentration in porewater fluctuated among all treatment dosages for both experiments. The concentration of ammonium was highest in the N744 plot and NFe plots $\left(4,867\right.$ and $4,773 \mu \mathrm{mol} \mathrm{l}^{-1}$, respectively; Fig. 11). The concentration of phosphate in porewater was highest in the $\mathrm{C}$ plot $\left(42.0 \mu \mathrm{mol} \mathrm{l}^{-1}\right)$. We frequently smelled $\mathrm{H}_{2} \mathrm{~S}$ in the porewater tubes during the summer.

\section{Discussion}

Most of the NSS belowground was in the form of rhizomes located, regardless of treatment, in about equal amounts in the $0-10$ and $10-20 \mathrm{~cm}$ soil layer, whereas the majority of the live root biomass remained in the upper $0-10 \mathrm{~cm}$ layer close to the added nutrient source. The NSS belowground in control plots is about twice that in the aboveground tissues, but only two thirds that in the highest dosed $\mathrm{N}$ plots because of the relative changes aboveground. The PSS above- and belowground in the control plots, in contrast, was about equal, but there was a reduction in the PSS belowground and an increase aboveground as the live biomass aboveground increased. This suggests a prominent role for $\mathrm{R} \& \mathrm{R}$ in the translocation of nutrients of unfertilized marshes. Darby and Turner (2008a) describe two significant seasonal translocation of $\mathrm{N}$ from below- to aboveground in these same marshes - one at the beginning and one at the end of the growing season. If the availability of critical limiting nutrients increased, then it seems logical to expect that the size and physiological intensity of the foraging structures would diminish somewhat, and most prominently when at their seasonal maximum, which is when we sampled.

Two kinds of responses were observed in experimental plots which support the more tenuous conclusion that the $\mathrm{N}: \mathrm{P}$ ratios, by themselves, indicate $\mathrm{N}$ and $\mathrm{P}$ growth limitation of the above- and belowground biomass, respectively. The first observation is that the accumulation of the aboveground biomass at the study site was clearly limited by $\mathrm{N}$, and not by $\mathrm{P}, \mathrm{Fe}$, or a combination of all three

Table 2 The nitrogen and phosphorous standing stock $\left(\mathrm{g} \mathrm{m}^{-2}\right)$ of above- and belowground live and dead and N:P molar ratios for each nitrogen addition treatment

\begin{tabular}{|c|c|c|c|c|c|c|c|c|c|c|c|c|}
\hline \multirow[t]{3}{*}{ Treatment $\left(\mathrm{g} \mathrm{m}^{-2}\right.$ month $\left.^{-1}\right)$} & \multicolumn{6}{|c|}{ Aboveground } & \multicolumn{6}{|c|}{ Belowground } \\
\hline & \multicolumn{2}{|c|}{ Nitrogen } & \multicolumn{2}{|c|}{ Phosphorus } & \multicolumn{2}{|l|}{$\mathrm{N}: \mathrm{P}$} & \multicolumn{2}{|c|}{ Nitrogen } & \multicolumn{2}{|c|}{ Phosphorus } & \multicolumn{2}{|l|}{$\mathrm{N}: \mathrm{P}$} \\
\hline & Live & Dead & Live & Dead & Live & Dead & Live & Dead & Live & Dead & Live & Dead \\
\hline 0 & 6.4 & 2.6 & 0.86 & 0.19 & 16.4 & 30.8 & 22.6 & 45.3 & 4.07 & 2.7 & 32.7 & 37.2 \\
\hline N 46 & 8.4 & 2.5 & 0.93 & 0.21 & 19.9 & 26.8 & 24.7 & 47.9 & 1.51 & 2.39 & 36.0 & 44.6 \\
\hline N 93 & 8.9 & 3.2 & 0.95 & 0.24 & 20.8 & 29.2 & 20.1 & 48.8 & 2.29 & 2.77 & 33.1 & 38.9 \\
\hline N 186 & 12.4 & 3.6 & 1.28 & 0.22 & 21.3 & 35.8 & 15.9 & 47.5 & 4.68 & 2.25 & 33.4 & 46.5 \\
\hline N 372 & 16.9 & 5.9 & 1.47 & 0.48 & 25.3 & 27.2 & 26.5 & 43.7 & 7.83 & 2.67 & 33.0 & 36.2 \\
\hline N 744 & 18.7 & 8.4 & 1.56 & 0.55 & 26.5 & 33.5 & 18.4 & 41 & 1.87 & 2.19 & 36.9 & 45.2 \\
\hline Average & 11.9 & 4.4 & 1.18 & 0.31 & 21.7 & 30.5 & 21.4 & 45.7 & 3.7 & 2.5 & 34.2 & 41.4 \\
\hline
\end{tabular}

The highest values are listed in bold. 
Table 3 The nitrogen and phosphorous standing stock $\left(\mathrm{g} \mathrm{m}^{-2}\right)$ of aboveground and belowground live and dead biomass and the N:P ratios for each factorial experiment treatment

\begin{tabular}{|c|c|c|c|c|c|c|c|c|c|c|c|c|}
\hline \multirow[t]{3}{*}{ Treatment $\left(\mathrm{g} \mathrm{m}^{-2}\right.$ month $\left.^{-1}\right)$} & \multicolumn{6}{|c|}{ Aboveground } & \multicolumn{6}{|c|}{ Belowground } \\
\hline & \multicolumn{2}{|c|}{ Nitrogen } & \multicolumn{2}{|c|}{ Phosphorus } & \multicolumn{2}{|l|}{$\mathrm{N}: \mathrm{P}$} & \multicolumn{2}{|c|}{ Nitrogen } & \multicolumn{2}{|c|}{ Phosphorus } & \multicolumn{2}{|l|}{$\mathrm{N}: \mathrm{P}$} \\
\hline & Live & Dead & Live & Dead & Live & Dead & Live & Dead & Live & Dead & Live & Dead \\
\hline 0 & 6.4 & 2.6 & 0.86 & 0.19 & 16.4 & 30.8 & 11.7 & 45.3 & 0.79 & 2.7 & 32.7 & 37.0 \\
\hline N 744 & 18.7 & 8.4 & 1.56 & 0.55 & 26.5 & 33.5 & 12.5 & 43.7 & 0.84 & 2.7 & 36.9 & 45.2 \\
\hline $\mathrm{P}$ & 6.3 & 1.9 & 0.88 & 0.15 & 15.8 & 28.2 & 9.0 & 41.0 & 0.54 & 2.0 & 31.2 & 41.9 \\
\hline NP & 20.0 & 7.8 & 1.97 & 0.55 & 22.4 & 31.5 & 5.6 & 36.7 & 0.39 & 1.9 & 33.3 & 40.5 \\
\hline $\mathrm{Fe}$ & 8.0 & 2.6 & 0.99 & 0.18 & 17.9 & 31.7 & 5.0 & 36.4 & 0.33 & 2.0 & 34.2 & 34.5 \\
\hline $\mathrm{NFe}$ & 15.5 & 6.3 & 1.76 & 0.39 & 19.4 & 35.3 & 5.9 & 36.8 & 0.38 & 2.4 & 38.5 & 47.6 \\
\hline $\mathrm{PFe}$ & 7.8 & 3.0 & 1.07 & 0.21 & 16.2 & 31.8 & 4.29 & 42.8 & 0.25 & 2.0 & 35 & 41.8 \\
\hline $\mathrm{NFeP}$ & 11.9 & 4.8 & 1.43 & 0.30 & 22.2 & 34.6 & 5.43 & 38.8 & 0.36 & 2.1 & 36.1 & 41.7 \\
\hline Average & 12.1 & 4.7 & 1.33 & 0.32 & 19.6 & 32.2 & 6.6 & 40.4 & 0.42 & 2.2 & 34.7 & 41.3 \\
\hline
\end{tabular}

The highest values are in bold font

elements. The aboveground live biomass, and the stem number and length, responded positively to increases in $\mathrm{N}$, and equaled that in plots with $\mathrm{N}$ applied in combination with $\mathrm{P}$ or $\mathrm{Fe}$ or $\mathrm{P}+\mathrm{Fe}$. Furthermore, no stimulation in the growth of aboveground biomass occurred when $\mathrm{P}$ or $\mathrm{Fe}$ was applied separately or together. No difference in the NSS among treatment levels was seen and some native $\mathrm{N}$ may have been incorporated into the plant tissue. The molar N:P ratio in the control and experimental plots was also indicative of $\mathrm{N}$ limited aboveground growth, but not definitively so. These changes in the aboveground biomass to nitrogen additions are consistent with the experimental results described for east coast salt marshes (Morris 1991) and the analysis of annual variations for salt marshes in Barataria Bay, LA (Visser and Sasser 2006).

A different response to nutrient additions was observed when the accumulation of belowground biomass was

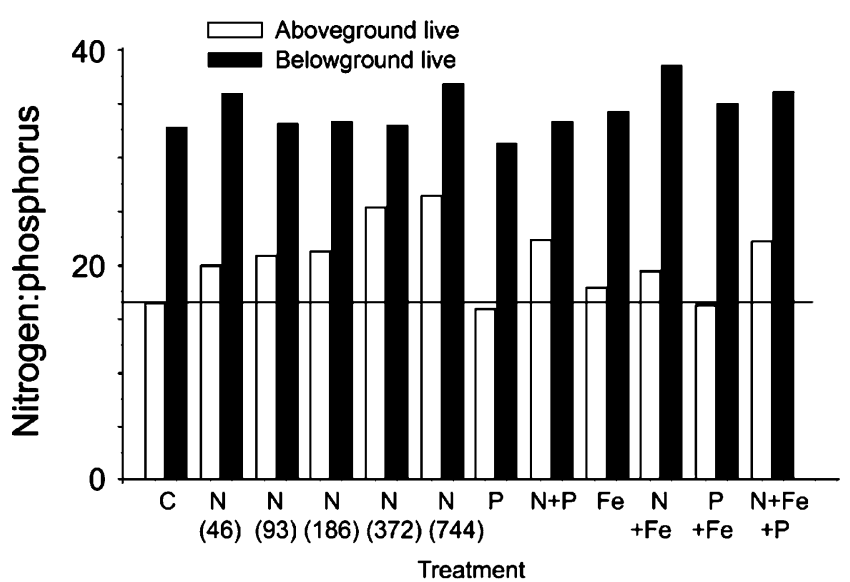

Fig. 9 The N:P molar ratios of live above- and belowground biomass by treatment. A ratio $<33$ or $>33$ (above or below the horizontal line) is an indicator of $\mathrm{N}$ or $\mathrm{P}$ growth limitation, respectively examined. The belowground biomass decreased in all plots that had $\mathrm{P}$ added, whether as $\mathrm{P}$ alone or in combination with $\mathrm{N}, \mathrm{Fe}$, or $\mathrm{N}+\mathrm{P}$, but the belowground biomass did not change in response to $\mathrm{N}$ additions alone. The $\mathrm{R} \& \mathrm{R} /$ shoot ratio decreased with $\mathrm{N}$ additions because the live aboveground biomass increased, and because the live belowground biomass decreased, but not proportionally. The belowground biomass was lower than in the control plots when $\mathrm{P}$ was added. In other words, the plant's resource allocation belowground (biomass for nutrient foraging and storage) was reduced when $\mathrm{P}$ was added. This is not evidence of $\mathrm{P}$ 'growth limitation' in the usual sense of that term, which is to mean that growth increased in proportion to $\mathrm{P}$ availability. It does support the idea that root foraging is relaxed as $\mathrm{P}$ availability increases.

The iron addition experiment was initiated from a sense of curiosity, e.g., if iron might bind with phosphate under anaerobic conditions and release it at other times. We did not know whether the above- or belowground biomass accumulation would change because of these iron additions. There was no response to the iron additions aboveground, but the changes belowground mimicked the changes in the $\mathrm{P}$ addition plots. These results support the hypothesis that the presence of iron has a conservative influence on $\mathrm{P}$ availability in these marshes. Phosphorus conservation might have the same effect as $\mathrm{P}$ addition-i.e., a lower belowground biomass.

The accumulation of PSS belowground may have been restricted by other factors than the availability of $\mathrm{P}$. Bacterial numbers in rooting zones, for example, are higher in phosphorus-treated plots (Sundareshwer et al. 2003). There is a suggestion of a lower PSS with increasing N:P ratio in the tissues (Fig. 10b), and there was no difference in phosphate concentration in the porewater of plots with the 
Fig. 10 The relationships among the standing stocks of live biomass, NSS and PSS vs. the N: molar ratios and the $\mathrm{N}$ dosage rates. a. Above- and belowground biomass and $\mathrm{N}: \mathrm{P}$ ratios of live tissues. $\mathbf{b}$ NSS and PSS of aboveand belowground live tissues vs. tissue N:P ratios. c Aboveground live biomass and $\mathrm{N}$ dosage, including with various combinations of $\mathrm{P}$ and $\mathrm{Fe}$. $\mathbf{d}$ Belowground live biomass and the $\mathrm{N}$ dosages with various combinations of $\mathrm{P}$ and Fe. The linear regressions in (a) and (b) are of untransformed data $(p<0.01)$. $\mathbf{c}$ is a polynomial fit of the data $\left(R^{2}=0.88\right.$; $p<0.001)$. Overlapping data in panels (c) and (d) are indicated by larger symbols and slight offsets
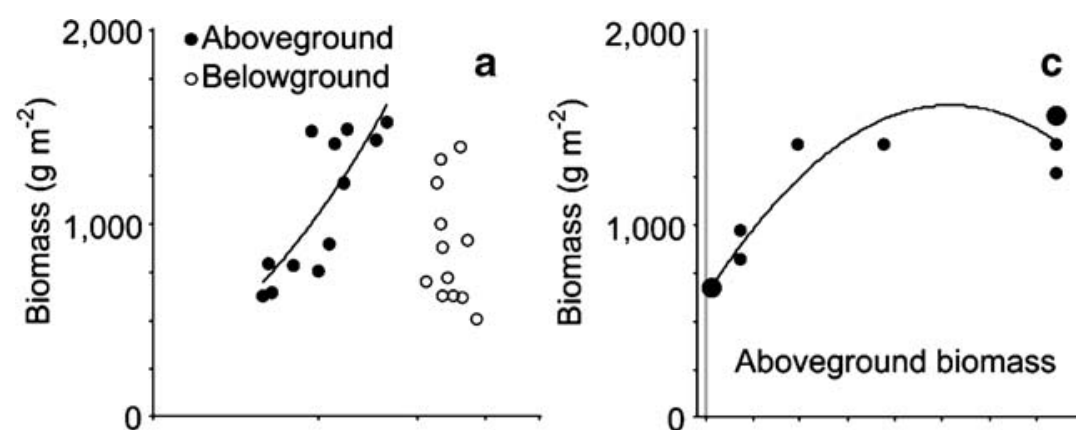

Aboveground biomass
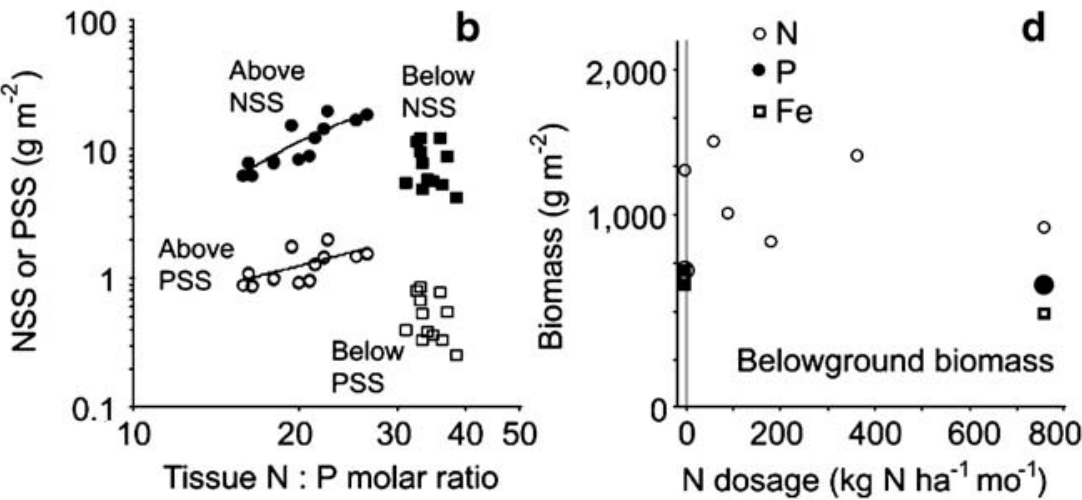

added $\mathrm{P}$ compared to added $\mathrm{N}$. These two results are consistent with the hypothesis that $\mathrm{P}$ is limiting for soil microbes and/or that the belowground plant biomass is relieved of some, but not all, of its need to forage for nutrients when $\mathrm{P}$ availability is increased.

One of the striking results of this experiment is the different responses to $\mathrm{N}$ and $\mathrm{P}$ additions by the belowground and the aboveground biomass. The literature is replete with the conclusion that salt marshes are limited by $\mathrm{N}$ availability. This conclusion is certainly an accurate description of the plant's aboveground response to nutrient

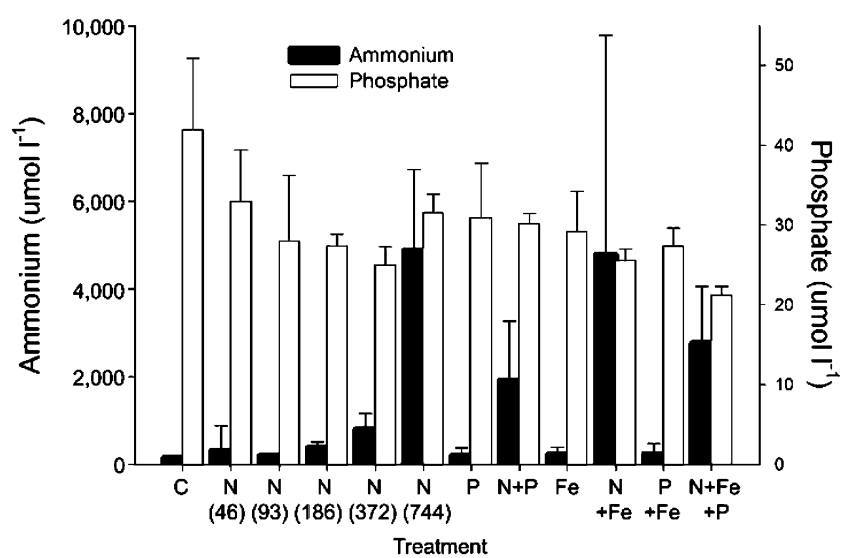

Fig. 11 Average porewater ammonium and phosphate at a depth of 10 $\mathrm{cm}\left(\mu \mathrm{mol} 1^{-1} ; \mu \pm 1 \mathrm{SD}\right)$ in the treatment plots during the growing season additions and perhaps of the plant's total production. However, phosphorus, not nitrogen, appears to induce a response by the plant belowground, and this response is to decrease the accumulation of plant biomass as more $\mathrm{P}$ becomes available. A decrease in organic-rich soils could compromise the long-term survival of a salt marsh where organic accumulation is essential to maintain a physiologically satisfactory position with regard to sea-level rise, or where R\&R are necessary to successfully resist the erosive effects of storm surges or waves. Management implications of this conclusion are that some responses to eutrophication are immediate and, in this example, may produce a disproportionate change in belowground biomass and organic matter accumulation, but there are other consequences that may be more subtle, and also catastrophic. A marsh may appear healthy because there is the visual richness of a relatively high amount of aboveground biomass, but be unhealthy from an ecosystem point of view because soil accretion is not keeping up with relative sea level rise (Turner et al. 2004). In this sense, which is a long-term view, a salt marsh ecosystem may be limited by phosphorus, not by nitrogen. There are, in other words, several contexts in which the idea of a limiting nutrient can be usefully applied, e.g., total plant production, part of the plant, or organic accretion. Monitoring programs that are limited to observations on the aboveground plant biomass will, of course, miss an important and sensitive indicator(s) of salt marsh health if the belowground portion of the ecosystem is excluded from consideration. 
Acknowledgments We thank J. Baustian, A. Darby, J. M. Lee, C. Milan, T. A. Oswald, J. Spicer, and E. M. Swenson for assistance in the field sampling and laboratory support, and J. Geaghan and E. M. Swenson for assistance with the statistical analyses. Anonymous reviewers made many helpful comments on a draft manuscript. Support was provided by the NOAA Coastal Ocean Program MULTISTRESS Award No. NA16OP2670 to Louisiana State University and a Louisiana Board of Regents Fellowship to FAD.

\section{References}

Blum, L.K. 1993. Spartina alterniflora root dynamics in a Virginia marsh. Marine Ecology Progress Series 102: 69-178.

Carpenter, S., N.F. Caraco, D.L. Correll, R.W. Howarth, S.N. Sharpley, and V.H. Smith. 1998. Nonpoint pollution of surface waters with phosphorous and nitrogen. Issues in Ecology 3: 1-12.

Dame, R.F., and P.D. Kenny. 1986. Variability of Spartina alterniflora primary production in the euhaline North Inlet estuary. Marine Ecology Progress Series 32: 71-80.

Darby, F.A., and R.E. Turner. 2008a. Below- and aboveground Spartina alterniflora production in a Louisiana salt marsh. Estuaries and Coasts 31:223-231.

Darby, F.A., and R.E. Turner. 2008b. The consequences of eutrophication to salt marsh roots, rhizomes, and soils. Marine Ecology Progress Series (in press).

Deegan, L.A. 2002. Lessons learned: The effects of nutrient enrichment on the support nekton by seagrass and salt marsh ecosystem. Estuaries 25: 727-742.

Giblin, A.E., and R.W. Howarth. 1984. Porewater evidence for a dynamic sedimentary iron cycle in salt marshes. Limnology and Oceanography 29: 47-63.

Huang, X., and J.T. Morris. 2005. Distribution of phosphatase activity in marsh sediments along an estuarine salinity gradient. Marine Ecology Progress Series 292: 75-83.

Koerselman, W., and A.F.M. Meuleman. 1996. The vegetation N:P ratio: A new tool to detect the nature of nutrient limitation. Journal of Applied Ecology 33: 1441-1450.

Morris, J.T. 1988. Pathways and controls of the carbon cycle in salt marshes. In The ecology and management of wetlands, ed. D. D. Hooks, 497-510. London: Croom Helm.
Morris, J.T. 1991. Effects of nitrogen loading on wetland ecosystems with particular reference to atmospheric deposition. Annual Review of Ecology and Systematics 22: 257-279.

Ponnamperuma, F.N. 1965. The mineral nutrition of the rice plant. Johns Hopkins Press: Baltimore, Maryland.

Rabalais, N.N. 2002. Nitrogen in aquatic ecosystems. Ambio 31: 102-112.

Schubauer, J.P., and C.S. Hopkinson. 1984. Above- and belowground emergent macrophyte production and turnover in a coastal marsh ecosystem, Georgia. Limnology and Oceanography 29: 10521063 .

Sundareshwar, P.V., J.T. Morris, E.K. Koepfler, and B. Fornwalt. 2003. Phosphorus limitation of coastal ecosystem processes. Science 299: 563-565.

Turner, R.E., and N.N. Rabalais. 1999. Suspended particulate and dissolved nutrient loadings to Gulf of Mexico estuaries, In Biogeochemistry of Gulf of Mexico Estuaries, eds. T. S. Bianchi, J. R. Pennock, and R. W. Twilley, 89-107. New York: Wiley \& Sons, Inc.

Turner, R.E., E.M. Swenson, C.S. Milan, J.M. Lee, and T.A. Oswald. 2004. Below-ground biomass in healthy and impaired marshes. Ecological Research 19: 29-35.

United States Environmental Protection Agency, 2002. Methods for evaluating wetland conditions: Vegetation-based indicators of wetland nutrient enrichment. Office of Water, U. S. Environmental Protection Agency, Washington, D C. EPA-822-R-02-024.

Valiela, I., and J.M. Teal. 1974. Nutrient limitation in salt marsh vegetation. In Ecology of Halophytes, ed. R.J.N.W. Reimold, Queen, 563-574. New York: Academic Press.

Valiela, I., J.M. Teal, and N. Persson. 1976. Production and dynamics of experimentally enriched salt marsh vegetation: Belowground biomass. Limnology and Oceanography 21: 245-252.

Visser, Y.M., and C.A. Sasser. 2006. The effect of multiple stressors on salt marsh end-of-season biomass. Estuaries and Coasts 29: 331-342.

Vitousek, P.M., R. Aber, R.W. Howarth, G.E. Likens, P.A. Matson, D.W. Schindler, W.H. Schilesinger, and G.D. Tilman. 1997. Human alteration of the global nitrogen cycle: Causes and consequences. Ecological Applications 7: 737-750.

Wigand, C., R.A. Mckinney, M.A. Charpenter, M.M. Chintala, and G.B. Thursby. 2003. Relationships of nitrogen loading, residential development, and physical characteristics with plant structure in a New England salt marsh. Estuaries 26: 1494-1504. 